\title{
UTILISATION OF DIGESTIBLE NUTRIENTS OF RATIONS CONTAINING BLACK GLUTEN AND RED RICE BY MINI REX RABBITS
}

\author{
${ }^{1}$ Romziah, Sidik. ${ }^{2}$ Emy, Kustanti., and.${ }^{3}$ Sri, Hidanah. \\ ${ }^{1}$ Professor in Animal Husbandry Department \\ ${ }^{2}$ Lecturer in Animal Husbandry Department \\ ${ }^{3}$ Doctor in Animal Husbandry Department \\ Faculty Veterinary Medicine of Universitas Airlangga. \\ (Correspondent author: romziah-s@ fkh.unair.ac.id).
}

\begin{abstract}
The utilisation of digestible nutrients in the feed rations containing black gluten and red rice by Mini Rex Rabbits were observed in the research study. The free variable of rations, including $P 0$ as commercial feed as the control ration, $P 1$ ration with white rice content, and $P 2$ and $P 3$ containing red and black gluten rice, respectively. The research used twelve Mini Rex Rabbits averaging 2 months of age and $1.95 \mathrm{~kg}$ body weight as experimental animals. They were divided into four groups with three replications. The experimental design was a Complete Randomised Design (4 $x 3$ replications). All animals received 10 $g / h / d$ of Alfalfa and a concentrated feed ration as well as the treatment groups, respectively.
\end{abstract}

Results of the experiment showed that the utilisation of digestible organic matter by the Mini Rex Rabbits were not significantly $(P>0.05)$ difference among the treatment groups. It ranged from about 51.18 to $53.24 \mathrm{~g} / \mathrm{h} / \mathrm{d}$. However, the utilisation of digestible crude protein was higher $(P<0.05)$ in the Mini Rex Rabbits which received the black gluten rice ration $12.85 \mathrm{~g} / \mathrm{h} / \mathrm{d}$. The utilisation of digestible fat was lower $(p<0.05)$ in the white rice feed ration; it was about $4.79 \mathrm{~g} / \mathrm{h} / \mathrm{d}$, while the utilisation of digestible crude fibre was higher $(p<0.05)$ in the commercial feed. The utilisation of digestible Nitrogen Free extract was higher $(p<0.05)$ in the black gluten rice feed ration, as it about $16.04 \mathrm{~g} / \mathrm{h} / \mathrm{d}$.

Key word: Black gluten, red rice, digestible, nutrient, rabbit.

\section{INTRODUCTION}

Mini Rex Rabbit have specific characteristics: medium size, rounded body, the ears are not too long, silky fur, active, and they find it easy to interact with humans or other animals. Their body weight is around 2.0 to $2.25 \mathrm{~kg}$, and the ideal body condition score ranges from about 3.0 to 3.25 (1). The Mini Rex rabbit is usually used as a pet animal. Nutrition programs are an important factor to achieve an ideal body condition score for the rabbit, besides other management factors like: individual selection based on the genotype and phenotype selection, health status, animal housing, sanitation and hygiene, and biosecurity which may affect the rabbit's performance.

The strategies used to prepare a good quality and quantity of rabbit feed included: 1. Learning about the Management function for Rabbit Care, 2. Choosing safe feed stuffs (forage, grain, vegetables), 3 . What are the achievements to do with rearing rabbits?, 4. Choosing the advantages of the ingredients which have specific benefits on the rabbit's health, production, and are immune modulators, antioxidants, anti-inflammatory, anti-microbials, and anti-cancer, and 5 . The proper method for feed processing $(2,4)$.

Black gluten and red rice are commonly used as a functional nutritious food in a human diet. It contains some anthocyanins that act as antioxidants, in addition to containing vitamin B and several mineral elements such as selenium, calcium, zinc, manganese and magnesium which have effects as being anti-cancer, anti-osteoporosis, lessening the risk of heart attack, bone and tooth defence, and inflammatory reduction (8). Both types of rice contain natural flavonoid compounds such as anthocyanin, and also have low energy content which sometimes has an effect on metabolic disorder prevention.

\section{OBJECTIVE OF THE RESEARCH}

The purpose of the research study is to observe the effects of black gluten and red rice in the rations on the digestibility and utilisation of digestible nutrients by Mini Rex Rabbits.

\section{METHODS}

Twelve male Mini Rex Rabbits averaging two-months old with an average body weight of about $1.8 \mathrm{~kg}$ were used as the experimental animals. Four variations of the feed ration included $\mathrm{P} 0$ as the commercial concentrate feed plus Alfalfa hay; P1 concentrate feed containing white rice combined with Alfalfa hay; P2 ration feed of red rice concentrate plus Alfalfa hay; P3 feed black gluten rice concentrate combined with Alfalfa hay, therefore, all of the experimental animals received $10 \mathrm{~g} / \mathrm{h} / \mathrm{d}$ of Alfalfa. The experimental animals were divided into four groups (P0, P1, P2, and P3) with three replications in each group. Feeding trials were run for a week during the eight week research period. The research used a Complete Randomised Design (4 treatments x 3 replication). The feed intake was measured every day as well as the total faeces excreted by the experimental animals. The sample feed and 
faeces were and analysed by the proximate method according to Weende's system. Some parameters accounted for including: organic matter, protein, fat, crude fibre, nitrogen free extract of percentage digestibility, and the utilisation of digestible nutrients.

The data was analysed by a statistical method based on the Analysis of Varian (ANOVA) method using SPSS software version 13.00 .

\section{RESULTS}

The protein content in the Alfalfa hay was about $24.80 \%$. In commercial feed it was $19.00 \%$, and in the other concentrate feeds it was $22.52,21.70$, and $23.10 \%$, respectively. The fat content was $7.10 \%$ in the concentrate containing white rice and the other concentrates ranged from about 9.30 to $10 \%$. The fibre matter in the commercial feed was $19.00 \%$, and 10.20 to $11.60 \%$ in the three other concentrate feeds. The nitrogen free extract ranged from about 32.40 to $37.00 \%$. The ash content in the commercial feed was $9.40 \%$, which is lower compared to the other concentrate feeds which ranged from 16.00 to $19.20 \%$, while the ash content in the Alfalfa hay was $13.90 \%$ (Table 1).

Table 2 showed the intake, digestibility and utilisation of digestible organic matter, crude protein, fat, crude fibre, and nitrogen free extract of the nutrients by the Mini Rex Rabbits. There were not significantly $(\mathrm{P}>0.05)$ different to the intake and utilisation of digestible organic matter among the treatment groups, although the digestibility of organic matter was significantly $(\mathrm{P}<0.05)$ different among the treatment groups. The higher $(\mathrm{P}<0.05)$ organic matter digestibility level was in the ration containing commercial concentrate feed. The organic matter's digestibility was not significantly $(p>0.05)$ different among the rations containing white, red, and black gluten rice. It ranged from about 97.21 to $97.52 \%$. Crude protein intake by the Mini Rex Rabbits was significantly higher $(\mathrm{P}<0.05)$ in groups $\mathrm{P} 1, \mathrm{P} 2$, and $\mathrm{P} 3$ which received rations containing white, red, or black gluten rice. These ranged from about 15.16 to $15.70 \mathrm{~g} / \mathrm{h} / \mathrm{d}$. The lower $(\mathrm{P}<0.05)$ crude protein intake $(11.88 \mathrm{~g} / \mathrm{h} / \mathrm{d})$ in the control group (P0) received only the commercial ration. Figure 2 shows the protein intake and utilisation of digestible protein by the Mini Rex Rabbits based on different rations.

Table 1. The Chemical Composition of Alfalfa hay, Commercial Rabbit Feed, Concentrate Feed Containing Black Gluten, White and Red Rice

\begin{tabular}{|c|c|c|c|c|c|c|}
\hline $\begin{array}{c}\text { Type of } \\
\text { Feed }\end{array}$ & $\begin{array}{c}\text { Dry } \\
\text { Matter, } \\
\%\end{array}$ & $\begin{array}{c}\text { Ash, } \\
\%\end{array}$ & $\begin{array}{c}\text { Crude } \\
\text { Protein, } \\
\%\end{array}$ & $\begin{array}{c}\text { Fat, } \\
\%\end{array}$ & $\begin{array}{c}\text { Crude } \\
\text { Fiber, } \\
\%\end{array}$ & $\begin{array}{c}\text { Nitrogen } \\
\text { Free } \\
\text { Extract, } \\
\%\end{array}$ \\
\hline Alfalfa hay & 88.30 & 13.90 & 24.80 & 1.90 & 19.70 & 28.00 \\
\hline $\begin{array}{c}\text { Commercial } \\
\text { feed }\end{array}$ & 94.50 & 9.40 & 19.00 & 9.30 & 19.70 & 36.90 \\
\hline $\begin{array}{c}\text { Black } \\
\text { Gluten Rice } \\
\text { Concentrate } \\
\text { feed }\end{array}$ & 94.50 & 19.20 & 22.52 & 10.00 & 10.40 & 32.40 \\
\hline $\begin{array}{c}\text { White Rice } \\
\text { Concentrate } \\
\text { feed }\end{array}$ & 95.60 & 18.00 & 21.70 & 7.10 & 11.60 & 37.00 \\
\hline $\begin{array}{c}\text { Red Rice } \\
\text { Concentrate } \\
\text { feed }\end{array}$ & 95.50 & 16.00 & 23.10 & 9.60 & 10.20 & 36.90 \\
\hline \multicolumn{1}{c|}{} & & & & & \\
\hline
\end{tabular}

Table 2. Intake, Digestibility and Utilisation of Digestible Organic Matter, Crude Protein, Fat, Crude Fiber, And Nitrogen Free Extract of Nutrients by Mini Rex Rabbits

\begin{tabular}{|c|c|c|c|c|}
\hline \multirow{2}{*}{ Parameter } & \multicolumn{4}{|c|}{ Treatment Group } \\
\hline & P0 & P1 & P2 & P3 \\
\hline $\begin{array}{c}\text { Organic Matter } \\
\text { Intake, } \mathrm{g} / \mathrm{h} / \mathrm{d}\end{array}$ & 53.18 & 54.58 & 52.46 & 52.56 \\
\hline $\begin{array}{c}\text { Digestibility of } \\
\text { Organic Matter, } \\
\%\end{array}$ & $98.13^{\mathrm{a}}$ & $97.52^{\mathrm{b}}$ & $97.21^{\mathrm{b}}$ & $97.35^{\mathrm{b}}$ \\
\hline $\begin{array}{c}\text { Digestible } \\
\text { Organic Matter, } \\
\text { g/h/d }\end{array}$ & 52.19 & 53.24 & 51.01 & 51.18 \\
\hline $\begin{array}{l}\text { Crude Protein } \\
\text { Intake, } \mathrm{g} / \mathrm{h} / \mathrm{d}\end{array}$ & $11.88^{\mathrm{b}}$ & $15.29^{\mathrm{a}}$ & $15.16^{\mathrm{a}}$ & $15.70^{\mathrm{a}}$ \\
\hline $\begin{array}{c}\text { Digestibility of } \\
\text { Crude Protein, \% }\end{array}$ & 79.67 & 81.87 & 80.45 & 81.84 \\
\hline $\begin{array}{l}\text { Digestible Crude } \\
\text { Protein, g/h/d }\end{array}$ & $9.46^{b}$ & $12.52^{a}$ & $12.20^{\mathrm{a}}$ & $12.85^{\mathrm{a}}$ \\
\hline Fat Intake, g/h/d & $5.84^{\mathrm{ab}}$ & $5.03^{b}$ & $6.56^{\mathrm{a}}$ & $6.71^{\mathrm{a}}$ \\
\hline $\begin{array}{c}\text { Digestibility of } \\
\text { Fat, } \% .\end{array}$ & 95.98 & 95.13 & 93.78 & 95.05 \\
\hline $\begin{array}{c}\text { Digestible Fat, } \\
\mathrm{g} / \mathrm{h} / \mathrm{d}\end{array}$ & $5.61^{\mathrm{a}}$ & $4.79^{b}$ & $6.15^{\mathrm{a}}$ & $6.38^{a}$ \\
\hline $\begin{array}{l}\text { Crude Fiber } \\
\text { Intake, } \mathrm{g} / \mathrm{h} / \mathrm{d}\end{array}$ & $12.34^{\mathrm{a}}$ & $8.16^{\mathrm{ab}}$ & $6.85^{c}$ & $7.16^{b}$ \\
\hline $\begin{array}{l}\text { Digestibility of } \\
\text { Crude Fiber, \% }\end{array}$ & $87.25^{b}$ & $92.02^{\mathrm{a}}$ & $92.22^{\mathrm{a}}$ & $93.03^{\mathrm{a}}$ \\
\hline $\begin{array}{c}\text { Digestible Crude } \\
\text { Fiber, g/h/d }\end{array}$ & $10.77^{\mathrm{a}}$ & $7.51^{\mathrm{b}}$ & $6.32^{c}$ & $6.66^{\mathrm{ab}}$ \\
\hline $\begin{array}{c}\text { Nitrogen Free } \\
\text { Extract Intake, } \\
\text { g/h/d }\end{array}$ & $23.12^{\mathrm{ab}}$ & $26.07^{\mathrm{a}}$ & $21.26^{\mathrm{b}}$ & $25.79^{\mathrm{a}}$ \\
\hline $\begin{array}{c}\text { Digestibility of } \\
\text { Nitrogen Free } \\
\text { Extract, } \% \\
\end{array}$ & $38.15^{b}$ & $70.97^{\mathrm{a}}$ & $60.52^{a}$ & $62.22^{\mathrm{a}}$ \\
\hline $\begin{array}{c}\text { Digestible } \\
\text { Nitrogen Free } \\
\text { Extract, } \mathrm{d} / \mathrm{h} / \mathrm{d} \\
\end{array}$ & $8.82^{c}$ & $18.50^{a}$ & $12.87^{b}$ & $16.04^{\mathrm{a}}$ \\
\hline
\end{tabular}

$\mathrm{a}, \mathrm{b}$, and ${ }^{\mathrm{c}}$ Superscript at the same row were significantly $(\mathrm{P}<0.05)$ different.

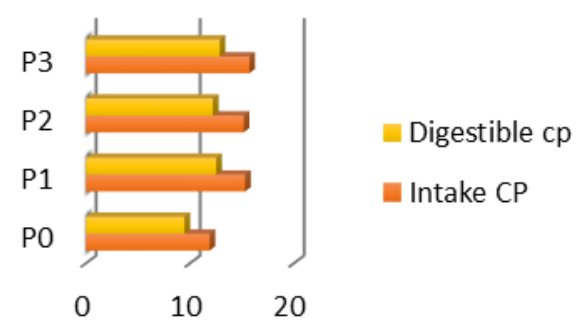

Figure 1. Intake and Digestible Crude Protein of Rations By Mini Rex Rabbit

The fat intake from the feed rations was higher $(\mathrm{P}<0 / 05)$ in the Mini Rex Rabbits who received black gluten and red rice, it rounded up to about 6.56 to $6.71 \mathrm{~g} / \mathrm{h} / \mathrm{d}$. However, the Mini Rex Rabbits that received the commercial feed and/or white rice did not have any differences in the level of fat intake $(\mathrm{P}>0.05)$, and it was lower when compared to the other groups; 5.03 to $5.84 \mathrm{~g} / \mathrm{h} / \mathrm{d}$. The digestibility of the fat was not significantly different $(\mathrm{P}>0.05)$, it ranged from about 93.78 to 95.98\%. The utilisation of digestible fat by the Mini Rex Rabbits was higher $(\mathrm{P}<0.05)$ in the groups which received black gluten and red rice at 6.38 and $6.15 \mathrm{~g} / \mathrm{h} / \mathrm{d}$, respectively. The level of digestibility of the crude fibre was higher $(\mathrm{p}<0.05)$ in the rabbit feed containing white, red, and or black gluten rice; 92.02 to $93.03 \%$. However, the crude fibre intake and the utilisation of digestible crude fibre was higher $(\mathrm{P}<0.05)$ in the rabbits that received the commercial ration 
(Figure 2). The level of nitrogen free extract was higher $(\mathrm{P}<0.05)$ in the Mini Rex Rabbits which were received white and black gluten rice, it ranged from about 25.79 to 26.07 $\mathrm{g} / \mathrm{h} / \mathrm{d}$. The pattern of the digestibility values of the nitrogen free extract was also higher $(\mathrm{P}<0.05)$ in the rations containing white, red, and or black gluten rice; 60.52 to $70.67 \%$. The digestibility of the commercial concentrate feed ration was very low $(\mathrm{P}<0.05)$, as it was only $38.15 \%$. Similar to the level of the utilisation of digestible nitrogen free extract, it was also higher $(\mathrm{P}<0.05)$ in the rabbits which received red, white, and or black gluten rice at about 12.87 to $18.50 \mathrm{~g} / \mathrm{h} / \mathrm{d}$. The utilisation of the nitrogen free extract was lower $(\mathrm{P}<0.05)$ in the Mini Rex Rabbits which received commercial feed, at only $8.84 \mathrm{~g} / \mathrm{h} / \mathrm{d}$ (see Figure 3).

\section{DISCUSSION}

Black gluten rice in the concentrate feed had the potential effect of increasing the digestibility of organic matter, crude fibre and the nitrogen free extract in the gastro-intestinal tract of the Mini Rex Rabbits. The purple colour of the black gluten rice indicates that any Anthocyanin - the natural flavonoid - has a positive effect as an antibacterial, antiinflammation, anti-diabetic and anti-cancer ingredient. In the research, it proved that the crude protein, fat, and nitrogen free extract intake increased, when the Mini Rex Rabbits consumed feed rations containing black gluten rice. The capacity of the rabbit caecum was about 10 times that of the stomach, which occupies about $40 \%$ of the gastrointestinal tract in the concentrate-fed rabbit. This condition could be greater in forage fed animals. The caecum of the rabbits contain some anaerobe microorganisms that are capable of digesting some fibre matter. However, if the number of soluble carbohydrates including glucose and fructose increases in the caecum, then the microbial protein will be increased, which may cause the rabbit to be unhealthy or sick. The black gluten and red rice which contains some Anthocyanin may improve the utilisation of the digestible crude protein, fat and nitrogen free extract and may help to better perform the ideal body weight and body condition score. The white rice in the rabbit's feed ration may increase the intake of organic matter and nitrogen free extract in the metabolism process in the Mini Rex Rabbits (4). So far, the commercial concentrate rabbit feed benefits in increasing organic matter and crude fibre digestibility, but did not influence the utilisation of digestible organic matter (3). The rabbits utilise a mechanism to expel slowly fermented fibre from the gastrointestinal tract, while the remaining is readily stored as fermented materials, and the endogenous nitrogen of the digested nutrients leaves from the ileum. The metabolism process of the feed is by enzymatic digestion in both the stomach and small intestine, as well as the digested nutrients moving through the tract. The small intestine in the rabbits is relatively short, so only readily digestible materials are extracted such as sugars, soluble protein and particulate starch (7). Adult rabbits appear to have little capacity to digest fat in the small intestine and lipase activity is restricted to the caecum (6). Excess quantity of fat in a diet may cause limited cellulose fermentation in the caecum. Fat deposition in fibre increases its density, and may be a factor in allowing the separation of the coarse fibres away from the caecum, as well as their subsequent excretion as components of hard faeces.

\section{CONCLUSION}

1. Rabbit feed rations containing black gluten rice increases the digestibility of organic matter, crude fibre and nitrogen free extract digested by the Mini Rex Rabbits.

2. Rabbit feed rations containing black gluten rice increases the intake of crude protein, fat, and nitrogen free extract digested by the Mini Rex Rabbits.

3. Rabbit feed rations containing black gluten rice increases the digestible crude protein, fat, and nitrogen free extract digested by the Mini Rex Rabbits.

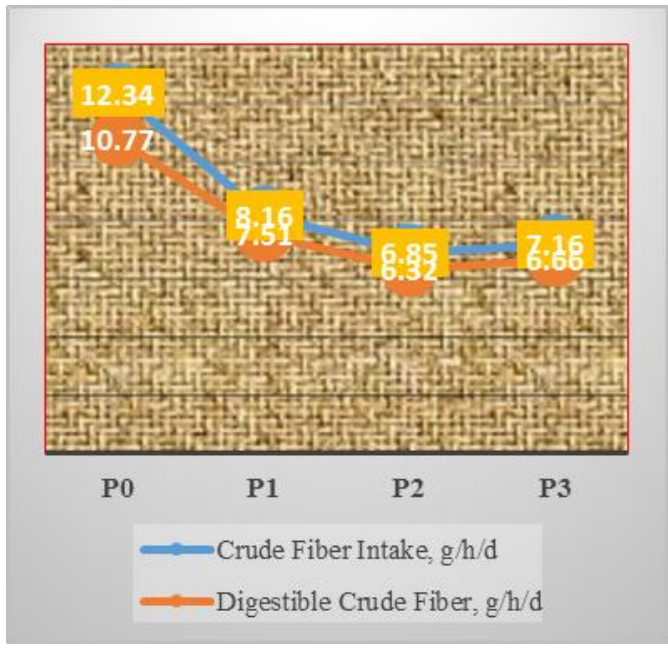

Figure 2. Intake and Digestible Crude Fiber of Ration by Mini Rex Rabbit

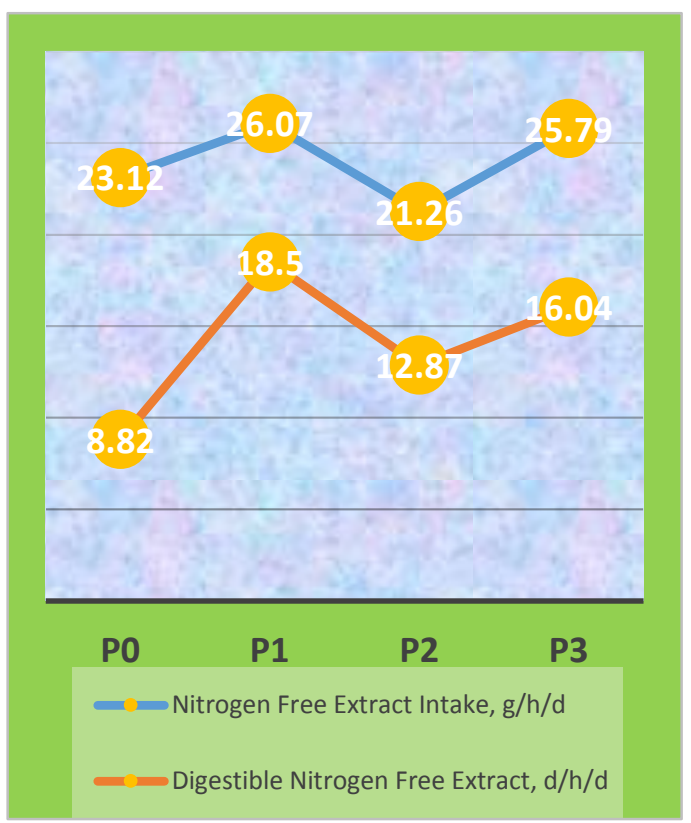

Figure 3. Intake and Digestible Nitrogen Free Extract of Rations by Mini Rex Rabbit

4. Rabbit feed rations containing red rice increases the intake of digestible crude protein and fat by the Mini Rex Rabbits. 
5. Rabbit feed rations containing white rice increases the intake of crude protein and nitrogen free extract by the Mini Rex Rabbits.

6. Commercial Rabbit feed increases the digestibility of 5 organic matter and crude fibre by the Mini Rex Rabbits. However, the digestible organic matter was not significantly $(\mathrm{P}>0.05)$ different to the rations containing white, red and or black gluten rice.

\section{References}

1. De la Fuente, L.F. and Rosell, and J.M. 2015. Body weight and body condition of breeding rabbits in commercial units. JAS Vol. 90 No. 9, p. 3252-3258.

2.Duyi S., Amit, B.D., Deka, S.C. 2017. Pigmented rice a potential source of bioactive compounds: a review. International Journal of Food. Wiley Online Library.

3.Halls, A.E. 2010. Nutritional Requirement for Rabbits. Nutreco Canada. www.nutrecocanada.com

4.Kushwaha, U.K.S. 2016. Black Rice: Research, History and Development.https://books.google.com/books?isbn=331 $\underline{9301535}$

5. Manjunatha, P, Mohan, K., Jayashankar, 2009. Effect of
Drier Brewer's Grains as a Source of Fiber in the Diet of Anggora Rabbits on the Growth Performance. Pakistan Journal of Nutrition 8 (8): 1167-1169.

6.Thierry, G. and Rachel, B._Use of digestible fiber in replacement to available carbohydrates: Effect on digestion, rate of passage and caecal fermentation pattern during the growth of the rabbit. https://doi.org/10.1016/S0301-6226(99)00123-2Wen

7. R.A. Leng, 2008. Digestion in the rabbit -a new look at the effects of their feeding and digestive strategies

8. Wen, H.L, Qi Xuan C., Jing M., and Tong W. 2011. Red and Black Rice Decrease Atherosclerotic Plaque Formation and Increase Antioxidant Status in Rabbits.The American Society for Nutritional Sciences. 